\title{
Monitoring the degradation of partly decomposable plastic foils
}

\author{
Gabriella RÉTHÁTI, ${ }^{1 *}$ Krisztina POGÁCSÁS, ${ }^{1}$ Tamás HEFFNER, ${ }^{2}$ \\ Barbara SIMON,${ }^{1}$ Imre CZINKOTA, ${ }^{1}$ László TOLNER, ${ }^{1}$ \\ Ottó KELEMEN, ${ }^{3}$ Viktória VARGHA ${ }^{2}$ \\ ${ }^{1}$ Szent István University, Institute of Environmental Sciences, \\ Department of Water and Waste Management, \\ H-2103 Gödöllő, Páter K. St. 1. rethati.gabriella@mkk.szie.hu (*corresponding author) \\ ${ }^{2}$ Budapest University of Technology and Economics, \\ Department of Physical Chemistry and Materials Science, \\ H-1111 Budapest, Müegyetem rkp.3-9.vvargha@mail.bme.hu \\ ${ }^{3}$ Qualchem Zrt., H-2072 Zsámbék Új Gyártelep
}

Manuscript received 07.21. 2014; revised 07. 20. 2014; accepted 05. 09. 2014

\begin{abstract}
We have monitored the behaviour of different polyethylene foils including virgin medium density polyethylene (MDPE), MDPE containing pro-oxydative additives $(238,242)$ and MDPE with pro-oxydative additives and thermoplastic starch (297) in the soil for a period of one year. A foil based on a blend of polyester and polylactic acid (BASF Ecovio) served as degradable control. The experiment was carried out by weekly measurements of conductivity and capacity of the soil, since the setup was analogous to a condenser, of which the insulating layer was the foil itself. The twelve replications allowed monthly sampling; the specimen taken out from the soil each month were tested visually for thickness, mechanical properties, morphological and structural changes, and molecular mass. Based on the obtained capacity values, we found that among the polyethylene foils, the one that contained thermoplastic starch extenuated the most. This foil had the greatest decrease in tensile strength and elongation at break due to the presence of thermoplastic starch. The starch can completely degrade in the soil; thus, the foil had cracks and pores. The polyethylene foils that contained pro-oxydant additives showed smaller external change compared to the virgin foil, since there was no available UV radiation and oxygen for their degradation. The smallest change occurred in the virgin polyethylene foil. Among the five examined samples, the commercially available BASF foil showed the largest extenuation and external change, and it deteriorated the most in the soil.
\end{abstract}

Keywords: polyethylene foil in soil, capacity, conductivity, tensile strength, elongation at break 


\section{Introduction}

Since the upswing of the plastic industry, there have been debates about reducing plastic waste whether by recycling, elimination or environmental or biodegradation. The time needed for their degradation is unknown for most plastics. These materials can resist degradation for centuries on waste disposal sites without light and oxygen. This problem could be solved by using and producing biodegradable plastic foils. However, it is very important to know what "biodegradable plastic" means, which can be easily misunderstood by the nonprofessional public [1]. It is not known how much time is needed for the plastic foils to be degraded, to what extent they degrade and how they affect the environment.

In our research, we have monitored the behaviour of polyethylene-based foils in the soil for one year, based on capacity and conductivity measurements. We investigated monthly the changes in thickness, molecular mass, mechanical, structural and morphological properties of the foils.

\section{Materials and methods}

The list of the examined foils is given in Tab. 1 . We prepared $6 \times 10-\mathrm{cm}$ bags from the plastic foils, in 12 repetitions.

Tab. 1. Composition of the examined plastic foils

\begin{tabular}{c|l}
\hline Signs & \multicolumn{1}{c}{ Composition } \\
\hline 340 & MDPE (medium density polyethylene) (Tisza Chemical Works, TVK) \\
\hline 238 & $\begin{array}{l}\text { MDPE + pro-oxidative additives (salts of metals with different oxidation } \\
\text { degree: Fe 0.072 \%, Co 0.015 \%, Zr 0.031 \%, Mn 0.006 \%, total metal } \\
\text { content: 0.124\%) (BME-Qualchem Zrt) }\end{array}$ \\
\hline 242 & $\begin{array}{l}\text { MDPE + pro-oxidative additives: Fe 0.051 \%, Co 0,025 \%, Zr 0,024 \%, } \\
\text { Mn 0.044 \% - total metal content: 0.144 \%) (BME-Qualchem Zrt) }\end{array}$ \\
\hline 297 & $\begin{array}{l}\text { MDPE + pro-oxydative additives (Mn 0.0103 \%, Co 0.0094 \%, total metal } \\
\text { content: 0.0197 \%) + thermoplastic starch (8.75\%) (BME-Qualchem Zrt) }\end{array}$ \\
\hline BASF & Mixture of thermoplastic polyester and polylactic acid (BASF, Ecovio) \\
\hline
\end{tabular}

The soil used in the experiment

The soil originated from Gödöllö-Szárítópuszta, from the experimental farm of Szent István University. It was a brown forest soil; its characteristics are listed in Tab. 2. 
Tab. 2. Parameters of the examined brown forest soil

\begin{tabular}{cccccccc}
\hline $\mathrm{K}_{\mathrm{A}}$ & $\mathrm{pH}_{\mathrm{KCl}}$ & $\mathrm{pH}_{\mathrm{H}_{2} \mathrm{O}}$ & $\begin{array}{c}\text { Total } \\
\mathrm{C} \%\end{array}$ & $\begin{array}{c}\mathrm{NO}_{3}-\mathrm{N}+ \\
\mathrm{NH}_{4}-\mathrm{N} \\
\mathrm{mg} / \mathrm{kg}\end{array}$ & $\begin{array}{c}\text { Total } \\
\mathrm{N} \%\end{array}$ & $\begin{array}{c}\mathrm{AL}-\mathrm{P}_{2} \mathrm{O}_{5} \\
\mathrm{mg} / \mathrm{kg}\end{array}$ & $\begin{array}{c}\mathrm{AL}-\mathrm{K}_{2} \mathrm{O} \\
\mathrm{mg} / \mathrm{kg}\end{array}$ \\
\hline 25 & 4.9 & 5.7 & 0.58 & 5.5 & 0.08 & 33 & 135 \\
\hline
\end{tabular}

The nutrient and moisture content of the soil was adjusted in order to prepare convenient circumstances for the degradation by the soil microorganisms. Thus, the carbon-to-nitrogen ratio was adjusted by $\mathrm{NH}_{4} \mathrm{NO}_{3}$ addition, and the proper moisture content was set by distilled water ( $60 \%$ of outdoor field capacity).

\section{Setup of the experiments}

The experimental setup is represented by Figure 1.

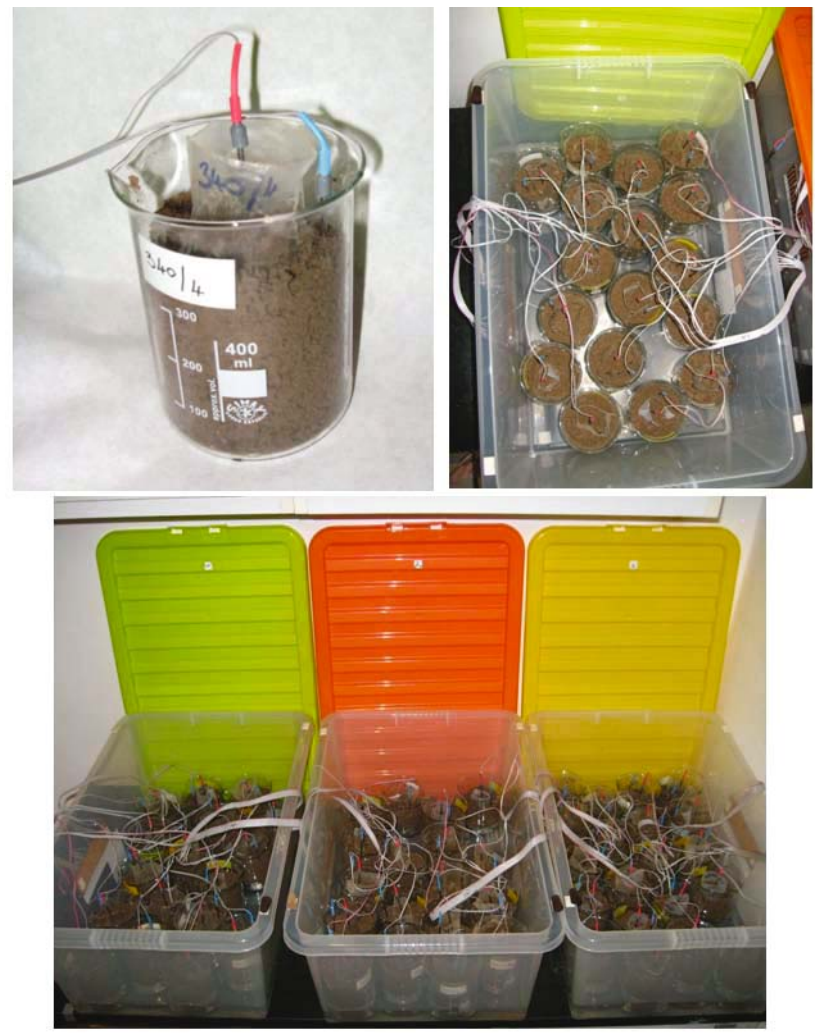

Fig. 1. The experimental design 


\section{The measuring cells}

The plastic bags were filled with soil and placed in a beaker full of soil; thus, the plastic bags were surrounded by soil. Measuring electrodes were put into the soil that was in the plastic bag and into the soil that surrounded it. The beakers were kept in plastic boxes in which the moisture content had previously been set, and it was aerated at certain times.

\section{Capacity and conductivity measurements}

The basic principle of the capacity measurement is that the plastic foil, along with the soil, behaves as a condenser, its armature is the soil, and the insulating layer is the plastic foil. The capacity correlation of this system is the following:

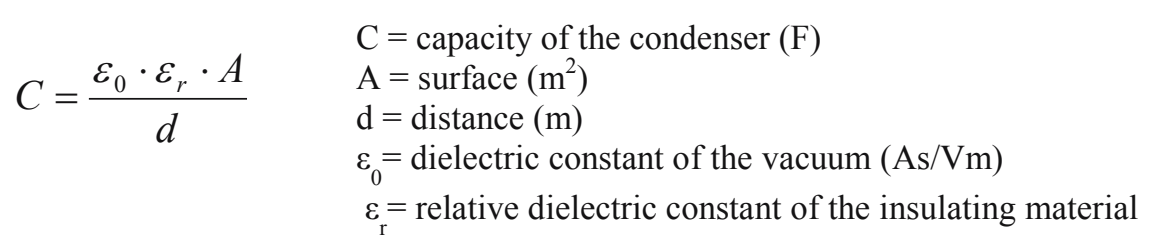

The capacity is directly proportional to the area of the armature (soil layers) and inversely proportional to the distance between them. Thus, the increase of the capacity values can be expected as the insulating layers (foils) become thinner.

The electrical conductivity is produced in the electric field by the movement of the charge carriers (electrons and ions); thus, in this case, we consider the soil as a conductor in which the conductivity depends on the soil moisture content and the insulating layer is the foil. Thus, we assume the phenomenon of the electrical conductivity when a crack occurs on the insulator.

As a reference, measuring cells were set in three repetitions, which only contained the prepared soil.

The measuring circumstances of thickness, molecular mass, mechanical, structural and morphological properties of the foils and the results are written in detail in Heffner, 2013 and Vargha, 2014 [2, 3].

\section{Results and discussions}

It can be seen in Figure 2 that the capacity was measured in all measuring cells. The soil sample that did not have foil can also behave as a condenser; its capacity can be several times higher than that of the measuring cells that contained foils.

During the measurements, we found that the soil moisture content decreased; thus, we had to rewet them twice in order to help degradation. It can be seen in the 
figure that as water was added on the $81^{\text {st }}$ and the $177^{\text {th }}$ day there was a sudden increase in capacity. The greatest capacity increase was found in the BASF and in the 297 foil. We assume that the soil microorganisms started to degrade the easily mobilizable organic polymers (polylactic acid, starch); thus, the structure of the foils changed, and microcracks were formed. The degradation of the abovementioned foils was confirmed by the change in mechanical properties, molecular mass and in surface morphology. The virgin polyethylene foil and the foils containing polyethylene and pro-oxidants did not show significant change in capacity during the measurements.
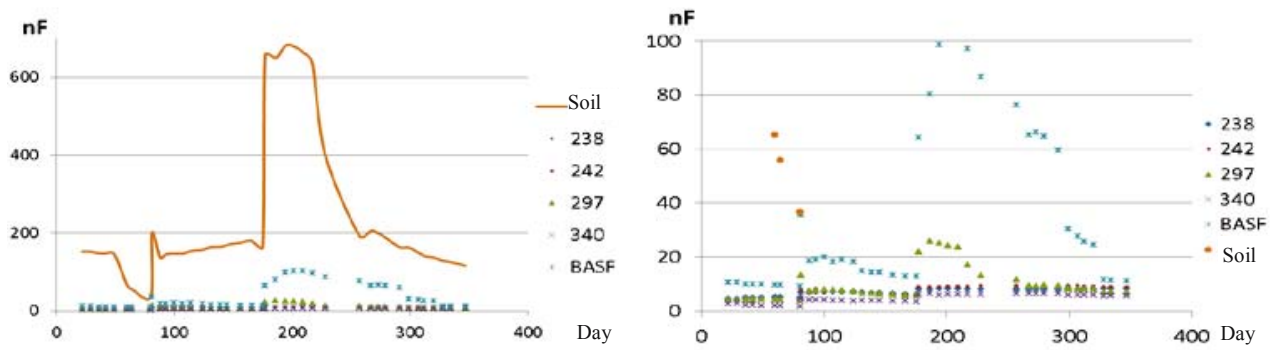

Fig. 2. Capacity change of the plastic foils in time

The changes in the conductivity values are shown in Figure 3. The conductivity values of the virgin polyethylene foil (340) showed a little change only after the addition of water, from which we can conclude that there was no significant degradation on this foil. Similarly, the polyethylene foils that contained pro-oxidative additives showed similar behaviour, i.e. their degradation was negligible, due to the lack of oxygen and UV radiation. However, the test results of the other properties of these foils (change in thickness, decrease in molecular mass and change in surface) suggest signs of initial degradation [2].
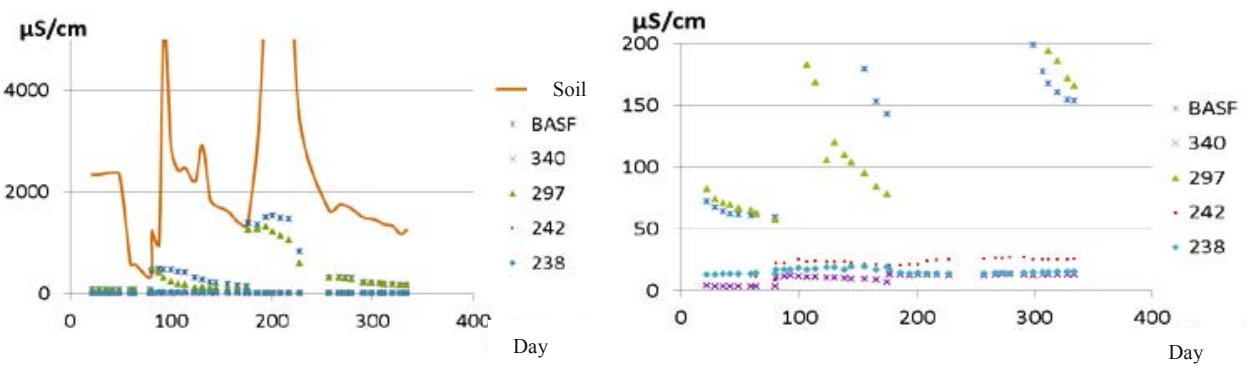

Fig. 3. Capacity changes of the plastic foils in time 
The conductivity values were significantly higher in the case of the polyethylene foil with thermoplastic starch and of the polylactic acid-based BASF foil compared to the virgin and pro-oxidant-containing polyethylene foils. This also supports the possibility of the biological degradation that we mentioned at the capacity results. We have to point out, however, that after the decomposition of the easily mobilizable organic materials further degradation of the polyethylene can only occur when the long chains are broken to smaller units $[4,5,6]$.

\section{Conclusion}

We found that the measurement of capacity and conductivity is suitable for the continuous monitoring of the degradation of the different plastic foils in soil. Within the one year of the experiment, only the polymers that have easily mobilizable organic material could be degraded; however, this does not mean that polyethylene-based foils are biologically degradable. Concerning the polyethylene foils with pro-oxidative additives, their degradation in soil is negligible due to the lack of required conditions (UV radiation, appropriate amount of oxygen).

\section{Acknowledgements}

The research was funded by the National Development Agency (NFÜ) Project Tech09-BDREVAM-2.

\section{References}

[1] Kyrikou, I., Briassoulis, D. (2007), Biodegradation of agricultural plastic films: A critical review. Journal of Polymere Environment 15, 125-150.

[2] Heffner, T. (2013), Környezetben lebomló fóliák viselkedése talajban. Biodegradálható fólia kidolgozása. Szakdolgozat, Budapesti Müszaki és Gazdaságtudományi Egyetem, Budapest.

[3] Vargha, V. (2014), Behavior of polyethylene films in soil. $2^{\text {nd }}$ International Conference on BioBased Polymers and Composites, Visegrád Hungary, August 24-28.

[4] Shah, A. A., Hasan, F., Hameed, A., Hameed, S. (2008), Biological degradation of plastics: A comprehensive review. Biotechnology Advances 26, 246-265.

[5] Scott, G. (2000), Green Polymers. Polymer Degradation and Stability 68, 1-7.

[6] Artham, T., Doble, M. (2008), Biodegradation of aliphatic and aromatic polycarbonates. Macromolecular Bioscience 8(1), 14-24. 